\title{
PERAN MEMETIC IKLAN DALAM PEMBENTUKAN BUDAYA BELANJA KONSUMEN DI KOTA PALU, SULAWESI TENGAH
}

\author{
Yulianti Bakari $^{{ }^{*}}$, Ikhtiar Hatta ${ }^{1}$, Citra Dewi ${ }^{1}$ \\ ${ }^{1}$ Program Studi Antropologi, FISIP, Universitas Tadulako \\ *E-mail: bakari_yulianti@yahoo.com
}

\begin{abstract}
This study presents an understanding of the role of advertising in shaping the world of shopping; therefore, the world of shopping does not only contain the transaction process in the buying and selling process. This study operationalizes the mimetic approach to analyzing the shopping phenomenon and advertising determinants. This study uses a research method that is generally carried out in anthropology, namely observation and interviews with consumers (especially teenagers) in Palu City. Besides that, it also develops deepening through the literature review. As a result, shopping today has become a lifestyle formed by the determination of advertising meaning that the advertising and shopping culture phenomena in this study are articulated as a phenomenon that intertwines to form a cultural system with its logic as a social phenomenon. As in Kaili's land, shopping expression certainly has its uniqueness amid the influence of globalization which encourages every consumer to follow a single image disseminated by advertisements.
\end{abstract}

Keywords: Lifestyle, Advertisement, Consumer Culture

\begin{abstract}
ABSTRAK
Kajian ini mengetengahkan satu pemahaman peran iklan dalam membentuk dunia berbelanja, karena itu dunia berbelanja tidak hanya mengandung proses transaksi dalam proses jual-beli. Kajian ini mengoperasionalkan pendekatan memetic untuk menganalisis fenomena berbelanja dan determinas iklan. Kajian ini menggunakan metode penelitian yang umumnya dilakukan dalam antropologi yakni observasi dan wawancara terhadap konsumen (terutama konsumen berusia remaja) di Kota Palu. Selain itu juga mengembangkan pendalaman melalui kajian pustaka. Hasilnya, berbelanja dewasa ini telah menjadi sebuah lifestyles atau gaya hidup yang dibentuk oleh determinasi iklan, artinya fenomena iklan dan budaya belanja dalam kajian ini terartikulasi sebagai satu fenomena yang berkelindan membentuk sistem budaya dengan logikanya sendiri sebagai sebuah gejala social, Seperti halnya di tanah Kaili, ekspresi berbelanja tentu memiliki kekhasan tersendiri di tengah pengaruh globalisasi yang mendorong setiap konsumen untuk mengikuti image tunggal yang didiseminasikan oleh iklan.
\end{abstract}

Kata Kunci: Lifestyle; Iklan; Budaya Konsumen

Submisi: 20 Agustus 2021

\section{Pendahuluan}

Dunia konsumerisme bukan sebuah praktek hidup sederhana yang hanya menyajikan proses transaksi di tempat berbelanja. Dunia ini menyisakan cukup banyak pertanyaan untuk mengungkap realitasnya dengan lebih baik dan setiap wilayah boleh jadi menghadirkan beragam praktek dan makna dari proses berbelanja mereka(Ahimsa-Putra, 2003: 28-29)
Palu sebagai sebuah kota, yang baru belakangan ini dunia belanjanya terisi sebuah ruang belanja yang merepresentasi tempat berbelanja di kota besar lainnya yang berkapasitas mall. Artinya kehadiran mall dapat dipastikan akan merubah image dan gaya belanja para konsumen di kota tersebut (Rahayu, 2017: 123). Perubahan orientasi tempat berbelanja dapat dipastikan akan 
mempengaruhi tampilan-tampilan proses berbelanja hingga pada konteks nilai (Mardiyana et al., 2012: 337; Jamil et al., 2018: 518)

Tulisan ini sebagai sebuah sketsa tentunya belum sampai pada sebuah penjelasan yang mendalam mengenai dunia konsumerisme di Kota Palu secara detail. Namun demikian tulisan ini mencoba merangsang tumbuhnya tulisan-tulisan lain yang lebih mendalam nantinya untuk melihat dinamika berbelanja di kota tersebut. Tulisan ini lebih memfokuskan pengkajiannya pada determinasi iklan dalam dunia belanja di Kota Palu.

\section{Belanja dan Budaya Konsumen}

Berbelanja sebagai sebuah fenomena budaya terjadi dalam sebuah masyarakat, kegunaan benda-benda selalu dibingkai oleh konteks budaya melalui perolehan, pengunaan dan pertukaran benda-benda, individu-individu kemudian mempunyai kehidupan sosial (Douglas and Isherwood 1979; Lury 1998:16). Menghubungkan proses makro reproduksi sosial dengan pembentukan proyek-proyek sosial konsumsi dan interaksi diantara mereka (Friedman dalam Lury 1998:72) bahwa membeli barang berarti membeli kesan dan pengalaman, dan kegiatan berbelanja bukan lagi suatu transaksi ekonomi "sederhana", melainkan lebih merupakan interaksi simbolis di mana individu membeli dan mengkonsumsi kesan (Featherstone 2001).

Dalam memahami fenomena berbelanja, ada baiknya menjelaskan istilah dari konsumsi dan belanja dalam tulisan ini yang disejajarkan satu sama lain. Menurut Mary Douglas dan Baron (1979) bahwa konsumsi bisa dikatakan sebagai bagian dari kebutuhan sosial yang memiliki relasi dengan orang lain melalui perantara bendabenda, atau disebut sebagai bagian dari proses sosial. Lebih lanjut, Douglas dan Insherwood mengungkapkan ada tiga alasan seseorang membeli suatu barang, yaitu 1) untuk memenuhi kebutuhan materi, 2) untuk kebutuhan psikis, 3) untuk penampilan (display) (Douglas and Isherwood 1979).
Sementara, pada prakteknya ada dua sifat proses berbelanja oleh konsumen yaitu konsumsi berdasarkan kegunaan atau bernilai guna, dan konsumsi dengan tujuan refresing atau kesenangan. Seorang konsumen memiliki kesadaran bahwa satu dari tujuan untuk menyambung hidup dan image dari ciptaannya sendiri (Miller 1991).

Berbelanja dalam analisis ini bukan hanya dipandang sebagai nilai guna dari sesuatu yang dibeli melainkan pentingnya melihat konsepsi makna terhadap sesuatu yang dibeli. Featherstone menjelaskan bahwa dalam memahami budaya konsumen masyarakat modern ada tiga cara pendekatan, pertama dengan melihat dominasi nilai simbolik dalam proses konsumsi, kedua dengan melihat pergeseran nilai dari etika ke estetika. Ketiga melihat dalam sistem acuan, seperti kebudayaan (Featherstone 2001).

Memperhatikan budaya konsumerisme kontemporer dicirikan pada peningkatan gaya hidup, produksi pertukaran dan pendayagunaan barang-barang konsumen (individu maupun kelompok) makin distrukturkan oleh aspek-aspek ekspresif yang disadari atau aspek-aspek simbolis barang-barang tersebut (Lury 1998:112). Pilihan Konsumsi dan gaya hidup melibatkan keputusan, mengidentifikasi, dan membedakan, serta mengklasifikasikan selera menurut orang lain (Featherstone 2001:42).

\section{Gaya Hidup (Lifestyle)}

Secara definisi, istilah gaya hidup (lifestyle) memiliki arti sosiologis yang lebih terbatas merujuk pada gaya hidup khas kelompok tertentu (Featherstone 2001:197). Bisa dikatakan pula gaya hidup adalah polapola tindakan yang membedakan antara satu orang dengan yang lainnya (Hermawan Kertajaya, et al.2003 dalam Handoko 2004). Lebih jelasnya adalah gaya hidup sebagai seperangkat praktik dan sikap suatu kelompok tertentu yang membedakan dirinya dengan orang lain dalam konteks tertentu. Sementara, Chaney (2004) membantu mendefinisikan gaya hidup 
(lifestyle) mengenai sikap, nilai-nilai, kekayaan, serta posisi sosial (Hendariningrum and Susilo 2014).

Dalam budaya konsumen kontemporer istilah gaya hidup, mengkonotasikan individualitas, mengekspresikan serta kesadaran diri stilistik, di mana orang mulai bersolek, pilihan makanan dan minuman, hiburan saat waktu luang, serta rumah, dan sebagainya dipandang sebagai indikator selera, serta rasa gaya (style) dari konsumen atau seseorang (Featherstone 2001). Gaya hidup oleh Hebdige (1988) dianggap sebagai karakter konsumsi modern yang merujuk pada kepekaan seseorang (konsumen). Seseorang dianggap membawa hasrat atau kepekaan yang tinggi terhadap proses konsumsi (Lury 1998:112).

Sebagai sebuah mode konsumsi, orang-orang berusaha menampilkan the self dan cita rasa mereka melalui pemilihan barang-barang pilihan serta kehadiran seseorang yang menegaskan suatu gaya hidup mudah diterima dan diidealkan. Hal ini tampak dari kecenderungan orang misalnya membeli shampo, sabun, tas branded, pakaian, dengan cara menunjukkan cita rasa, selera dari kelompoknya. Gaya hidup tidak hanya menekankan pada dimensi simbolik tetapi juga perjuangan membentuk posisi sosial atau kompetitif (Featherstone 2001; Lury 1998). Perjuangan untuk mendapatkan benda-benda posisional (bermerek), di mana kelompok masyarakat akan terus menginvestasikan barang-barang posisional dalam upaya mempertahankan status sosialnya atau seseorang seakan berlomba-lomba untuk mendapatkan barang-barang bermerek sebagai pengembangan gaya hidup tertentu. Dalam hal ini selera, pilihan konsumsi dan gaya hidup berkait dengan pekerjaan, dan fraksi kelas dalam mempengaruhi pemakaian benda-benda bermerek tersebut.

Para budaya konsumen tidak mengadopsi sebuah gaya hidup secara tidak sengaja melalui tradisi atau kebiasaan, melainkan menjadikan gaya hidup sebagai proyek kehidupan dan menampilkan individualitas dan selera gaya mereka baik itu melalui kekhasan pemakaian barangbarang, pakaian yang digunakan, pengalaman, praktek, dan disposisi tubuh yang didesain menjadi sebuah gaya hidup (Lury 1998:137).

Tidak dipungkiri bahwa dalam gaya hidup kontemporer, penampilan luar adalah segalanya. Penampilan tren dan mode warna dan gaya rambut, kendaraan dan pakaian yang digunakan, makanan yang dikonsumsi dapat mengidentifikasi individu (konsumen) dengan suatu ikon budaya cita rasa (Handoko 2004). Chaney melihat bahwa penampakan luar adalah salah satu situs yang penting bagi gaya hidup. Penampilan diri (tubuh) yang mengalami estetisasi, penampakan benda-benda, penampakan kehidupan glamor, citraan iklan merupakan suatu tontonan visual yang menghasilkan suatu citraan visual menjadi prasyarat hidup bagi budaya konsumen kontemporer (Chaney 2004).

Chaney melihat bahwa citraan luar telah menjadi sumberdaya yang mengangkat makna, mengkomunikasikan, tipu daya dan menata identitas sosial sehingga gaya hidup terartikulasi melalui transformasi secara konstan tontonan dari penampakan luar (Handoko 2004). Semua yang dimiliki akan menjadi budaya tontonan, seperti ungkapan kamu bergaya maka kamu ada, kamu tidak bergaya maka kamu tidak ada. Featherstone (2001) menyebutnya sebagai pertunjukan diri (presentation of self) yang tampak (the look). Lebih lanjut oleh Handoko (2004) menambahkan, Boudrillard melihat bahwa taraf produksi image tersebut telah membawa perubahan masyarakat secara kualitatif, dan kehidupan sehari-hari mengalami estetisikasi antara artistik dan fashionable.

Dalam pembentukan budaya citra dan budaya cita rasa di era budaya konsumen kontemporer, gempuran iklan yang menawarkan gaya visual terkadang menampilkan pesona dan memabukkan. Iklan merupakan bagian penting dalam proses pembentukan gaya hidup konsumsi (stylization). Iklan (advertisement) 
merepresentasikan gaya hidup dengan menanamkan secara halus arti penting citra diri untuk tampil didepan umum dan mempengaruhi pilihan cita rasa yang dibuat (Handoko 2004). Iklan juga dinyatakan sebagai alat manipulasi dimana konsumen dikendalikan dan dimanipulasi oleh produsen melalui media (Lago 2017). Meskipun tidak semua konsumen mempercayai iklan, namun menurut Lury (1998:90), iklan memiliki kekuatan terhadap objek yang justru datang dari kenyataan daya magisnya beraksi diatas kepingan kosong. Artinya makna iklan tidak akan berdampak jika objek telah mempunyai makna yang melekat sejak awal.

Seorang Kritikus terkemuka yakni Marshall Mcluhan mengungkapkan bahwa iklan sebagai karya seni terbesar abad-20, yang mana iklan bertindak sebagai penentu kecenderungan, mode, tren/style dan pembentuk kesadaran manusia modern. Iklan dipenuhi citraan (gambar, poster, bilboard, elektronic board, superboard dan lainnya). Citra dipandang sebagai cara utama di mana gagasan dan konsep-konsep dikemas untuk dipersembahkan ke dalam memori publik, untuk mengatur tindak tanduk publik karena tidak ada lagi batas mana yang privat maupun publik. Dalam kerangka fungsi komersial, citra-citraan merupakan alat persuasif untuk menembus akal sehat kritis, untuk menjajah dan menguasai batin, dan untuk membentuk mengatur tingkah laku (Piliang dalam Ibrahim 2004: 328). Dunia citra menjadi dunia yang dikodifikasi secara komersil mengikuti irama produksi dan konsumsi. Oleh karenanya citra-citraan komersil berfungsi sebagai satu bentuk rayuan yang memprovokasi konsumen dalam ilusi gaya hidup .

\section{Metode Penelitian}

Penelitian ini menggunakan pendekatan kualitatif, dan secara umum penelitian kualitatif membutuhkan penyajian data dalam bentuk uraian atau rangkaian kata-kata, data atau informasi yang sifatnya angka-angka (bila ada dan diperlukan) ditempatkan sebagai data sekunder atau pendukung data kualitatif (Silalahi 2009). Data penelitian ini dianalisis dengan menggunakan analisis deskriptif dengan unit analisis penetrasi iklan dalam membentuk perilaku konsumen dalam berbelanja.

Metode yang digunakan untuk menghimpun datum-datum dalam penelitian kualitatif ini menerapkan metode wawancara; dimana mereka yang dianggap layak menjadi informan dimintai informasi sekaitan dengan fokus penelitian, dan pengamatan yakni menerapkan sensitifitas pancaindra dan perasaan peneliti dalam menangkap informasi yang dapat dijadikan data. Mereka yang terpilih sebagai informan adalah para konsumen yang ditemui di pusat-pusat perbelanjaan dan bersedia untuk diwawancara. Lokasi penelitian diadakan di Kota Palu, Sulawesi Tengah.

\section{Hasil dan Pembahasan \\ Kekuatan Memetic dalam Membentuk Budaya Belanja Mengenal Secara Singkat Lifestyle}

Masyarakat konsumen Indonesia mutakhir tampaknya tumbuh beriringan dengan sejarah globalisasi ekonomi dan transformasi kapitalisme konsumsi (Haryanto Soedjatmiko 2008) yang ditandai dengan menjamurnya pusat perbelanjaan bergaya semacam shooping Mall, industri waktu luang, industri mode atau fashion, industri kecantikan, industri kuliner, industri nasihat, industri gosip, kawasan hunian mewah, apartemen real estate, gencarnya iklan barang-barang supermewah dan liburan wisata ke luar negeri, berdirinya sekolah-sekolah mahal, kegandrungan terhadap merk asing, makan serba-instan (fastfood), telepon seluler (HP), tentu saja serbuan gaya hidup lewat industri iklan dan televisi yang sudah sampai ke ruang - ruang yang paling pribadi, dan bahkan mungkin ke relung-relung jiwa manusia yang paling dalam (Raharjo Jati 2015).

Perburuan penampilan dan citra diri juga akan masuk dalam permainan 
konsumsi ketika gaya menjadi segalagalanya dan segala-galanya adalah gaya (Armaidy Armawi, 2007: 318-319; Pertiwi, 2018: 106-107) Kalau dalam gaya itu sendiri sudah melekat unsur permainan, maka sudah bisa dipastikan unsur-unsur yang membentuk gaya hidup akan menjadi komoditi dan ajang permainan konsumsi. Konsumsi menjadi sebuah tontonan. Apalagi produk yang memanfaatkan kekuatan citra bisa menjadi perlambang bagi kolektivitas sosial, terutama dengan memakai asoasinya dengan gaya hidup. (Rumondang et al., 2020: 47-48)

Tidak mengherankan industri jasa yang memberikan layanan untuk mempercantik penampilan (wajah, kulit, tubuh, rambut) telah dan akan terus tumbuh menjadi big business. Kini urusan bersolek tidak lagi melulu milik wanita, tapi kaum pria dalam memandang penampilan citra diri agaknya telah dilirik oleh industri kosmetika dan bisnis kecantikan di Tanah Air. Kini tidak hanya menjamur sampo khusus untuk pria dari berbagai merk, tetapi rumah-rumah mode juga akan mudah ditemui perlengkapan kosmetika khusus pria, berlebel For Men!

Tampaknya urusan 'tampangisme' atau 'wajahisme' (lookism/Faceism) kini mulai menjadi persoalan serius dalam perburuan kecantikan dan ketampanan untuk menjadi "Ter", tidak hanya di Pentas dunia fashion, tapi juga dalam kehidupan sehari-hari. Gejala seperti ini menurut Nancy Etciff seorang psikolog terkemuka asal Amerika menyebutnya dengan "Lookism". Lookism adalah teori yang menganggap bahwa bila lebih baik tampilan anda, maka lebih sukseslah Anda dalam kehidupan. Ini sangat relevan dengan abad citra, karena citra mendominasi persepsi, pikiran, dan juga penilaian akan penampilan wajah, kulit, atau tampang seseorang. Bahkan kebiasaan senyum, misalnya, sekarang ini tidak bisa lagi dianggap sepele. Senyum bisa menjadi modal simbolik dalam pergaulan sosial sehari-hari, di dunia kerja dan dunia bisnis, khususnya dalam dunia bisnis entertainment dan Public Relation. (Abdullah 2006)

Apa yang mungking relevan adalah bahwa dalam perburuan akan gaya hidup yang glamour, misalnya, para produsen dan industri hiburan mencoba melakukan bujuk rayu terhadap para pelanggan melalui ilusi-ilusi tentang diri (illusions of self). Artinya, bahwa mereka menarik para pelanggan seperti terlihat dalam bahasa-bahasa penampilan yang digunakan melalui industri-industri budaya massa.

\section{Ikon: Artis Sebagai Cerminan Gaya Hidup.}

Ketika dicermati lebih dalam prinsip iklan tidak jauh menyimpang dari teori Lookism di mana teori ini menilai bahwa bahwa bila lebih baik tampilan anda, maka lebih sukseslah dalam kehidupan karena itu kemudian berbagai iklan memanfaatkan artis dan berbagai pelaku seni yang telah menjadi public figure dijadikan scbagai ikon oleh sejumlah orang khususnya dari kelompok usia muda/remaja. Mereka menjadi pendukung ideologi yang sangat setia dengan berbagai apresiasi dan ekspresi sebagai wujud loyalitas dan kecintaan terhadap figure atau idolanya. Namun demikian perlu dijelaskan bahwa teori lookisme ini tidak bisa hanya dipahami sebagai teori yang menjelaskan tentang ketubuhan saja, tetapi lebih dari itu memuat tentang total image yang melekat pada artisnya (Chaney 2005).

Cara khusus selanjutnya yang dipilih seseorang untuk mengekspresikan diri, tak disangsikan merupakan bagian dari usahanya mencari gaya hidup pribadinya. Dengan cara yang sama manusia biasanya mengindividulisasikan gaya hidupnya, namun biasanya selalu ada kemiripan yang jelas dengan salah satu model gaya hidup yang telah dipraktekkan dan dipasarkan oleh suatu subkultur. Dalam menjajakan model gaya hidup dan memikat perhatian kita, subkultur biasanya milik psikologi manusia yang paling rawan: citra diri (selft image) (Fiske 1990). Manusia diombang- 
ambing oleh banyak janji psikologis mereka. Mereka menggelitik khayalan yang paling pribadi, mungkin dengan cara yang jauh lebih canggih dan halus dibandingkan dengan indoktrinasi rezim politik yang paling otoriter sekalipun. (Gandhi 2001)

Kegalauan dalam pencarian identitas diri, manusia kemudian benar-benar hidup ibarat mengarungi sebuah pasar, dengan begitu banyak kemungkinan yang ditawarkan oleh model gaya bidup yang saling bersaing. Dalam perburuan akan gaya ini, akan senantiasa mencari "pahlawan pahlawan" untuk ditokohkan dan ditiru (menduplikasi). Pencarian gaya ini adakalanya menggelisahkan, kadangkala menyakitkan, dan tak jarang pula menggairahkan.

Para pencari gaya ibarat wanita yang membolak-balik halaman mode di majalah popular untuk menemukan pola busana yang cocok untuk tampil menawan. Dengan demikian, perburuan gaya hidup berarti pula perburan penampilan diri di muka publik, di tengahtengah dunia benda kita, sekaligus perburuan identitas dipentas konsumsi massa. (Schlosser 2002)

Pahlawan-pahlawan yang dijadikan sebagai ikon untuk kalangan artis dapat kita kategorisasikan berdasarkan pendekatan aliran bermusiknya dan atas ranah berseni yang lainnya, seperti sinetron dan film. Pementasan musik, film, sinetron dalam hal ini sebagai panggung pementasan gaya hidup sekaligus sebagai gaya bidup itu sendiri.

\section{Wilayah Ekpresi Lifestyles di Tanah Kaili}

Lifestyles sebagai salah satu ciri kehadiran globalisasi yang telah menyebar ke sudut-sudut kehidupan (baik secara geografis ataupun periklanan) tentunya tidak akan menegasikan Tanah Kaili sebagai wilayah "empuk" mendiseminasikan nilai Lifestyles dan berbagai pelabelan subkultur yang mengikutinya; seperti sub kultur punk, dan berbagai model-model trend yang menegaskan identitas tertentu (Turner
2002). Siapapun tidak akan dengan muda mengelak dari gejala sosial tersebut, dan juga tidak akan memungkiri bahwa tanah Kaili sudah menginternalisasi nilai- nilai Lifestyles ke dalam kehidupan.

Pertanyaan akan muncul kemudian, mungkinkah gejala itu hadir di sini?" Berbagai aparatur pendukung memungkinkan para konsumen yang ada di wilayah ini "terinveksi" virus Lifestyles arti terinveksi di sini dimaknai sebagai sebuah kondisi yang mewabah pada konsumen dan kondisi terscbut membuat para konsumen yang terkena tidak cukup berdaya mengedepankan keinsyafannya dalam mengkonsumsi setiap barang yang mengandung gaya seperti adanya bandar udara, sistem telekomunikasi dan informasi juga cukup memadai, di antaranya jaringan telepon atau HP, jaringan TV dan yang tidak kalah pentingnya adalah keberadaan pusat perbelanjaan yang berdiri megah di pusat kota Palu, seolah menegaskan kehadiran pusat perbelanjaan di Tanah Kaili dalam duniia gaya hidup layaknya di kota-kota besar di Indonesia (Jakarta, Surabaya, Sumatra, Ujung Pandang, Bandu.ng).

$$
\text { Bukti penegasan pusat }
$$

perbelanjaan sebagai wilayah Lifestyles dikukuhkan dengan menghadirkan artisartis Ibukota dan lokal dalam jumpa artis. Pada beberapa moment. Masih teringat dalam catatan, awal keberadaan Malltatura (kini sudah roboh karena gempa) tepatnya pada hari kamis tanggal 27 Desember 2007 pusat perbelanjaan tersebut dipadati oleh sebagian besar kaum remaja dan konsumen lainnya. Tentunya dapat diduga, sebagian besar dari mereka datang dengan sengaja untuk menyaksikan secara live kehadiran artis yang menjadi idolanya. Sementara hal yang sama juga dilaksanakan di Palu Grand Mall sebagai salah satu tempat perbelanjaan yang masih bertahan pasca gempa dan tsunami 2008.

Ada hal yang menarik untuk diintegrasikan kemudian didiskusikan pada momen kehadiran grup musik (artis) tersebut di tempat-tempat perbelanjaan 
maupun ruang-ruang publik di Kota Palu, yang menarik kehadiran massa (konsumen) dalam membentuk serta memberikan pengaruh yang cukup kuat dalam membentuk gaya hidup dalam hal budaya berbelanja di Tanah Kaili. Termasuk juga hadirnya spot-spot baik counter-counter HP, salon kecantikan, counter pakaian, fast food di mall maupun pada pelaksaan event (di ruang publik), akan mendukung konsumen dalam memenuhi keinginan dan hasratnya dalam berbelanja untuk mencapai imajinasi ikon gaya hidupnya. Secara simbolik grup musik (artis) menghipnotis pengunjung yang hadir pada saat pelaksanaan event untuk menjadikannya sebagai ikon dalam berbagai hal, di antaranya, gaya berpakaian, bentuk tubuh, cara berbicara, cara berjalan, bahkan pilihan - pilihan makanan diidealisasi ke dalam anggota personil grup musik atau artis yang diidolakannya. Hal tersebut kemudian menghadirkan eksistensi dalam mengkonsumsi agar terlihat fashionable.

Dibalik kehadiran grup musik ibukota tersebut di Mall Tatura Ketika itu, menyisakan sebuah kondisi yang tidak sepenuhnya sama di pusat-pusat perbelanjaan atau shooping mall seperti di Makassar, Yogyakarta, Surabaya, dan Jakarta. Untuk gejala ini dapat dilihat dari aspek model arsitektur dimana model arsitektur yang ada relatif sangat konvensional diperuntukkan sekedar untuk berbelanja, bandingkan misalnya dengan mall yang ada di Makassar, Yogyakarta, dan Surabaya serta kota-kota besar lainnya. Tempat baik itu di mall maupun di ruang publik (space and place) dikemas tidak sekedar untuk berbelanja tetapi lebih dari itu juga sebagai arena memperagakan gaya hidupnya, para pengunjung (konsumen) seolah menjadi peragawati atau peragawan dalam sebuah komunikasi simbolik, baik dalam kondisi keterpaduan simbol, maupun dalam kondisi simbol yang acak-acakan.

Model arsitekturnya umumnya melingkar atau persegi dan tiap counter maupun spot hanya dibatasi oleh kaca yang transparan atau meja pendek, dengan demikian satu sama lain dapat saling melihat sebagai salah satu bentuk ekspresi dalam mengkomunikasikan setiap citraan (image). Dengan demikian mall dan pusatpusat perbelanjaan lainnya serta ruang publik yang dijadikan sebagai tempat event, oleh para konsumen dijadikan sebagai wilayah ekspresi simboliknya. Keunikan lainnya adalah, setiap orang memihiki posisi yang sejajar dalam mengkomunikasikan setiap nilai yang ada dibalik ekspresi berpakaian dan berdandannya.

\section{Kesimpulan}

Fenomena berbelanja yang dipraktekkan oleh konsumen di Tanah Kaili yang dipaparkan di atas telah menjelaskan satu realitas memetic yang dipengaruhi oleh kehadiran iklan. Iklan telah berhasil melakukan penetreasi membentuk dan menyebarkan image tersendiri yang mendekatkan pada figure para tokoh yang menjadi bintang iklan. Iklan melalui berbagai wujud dan media yang digunakan menyebarkan kesadaran berbelanja yang diinginkan oleh produsen dan pembuat iklan. Namun demikian kekuatan memetic iklan dalam menyebarkan dan membentuk selera berbelanja konsumen juga tetap membutuhkan dukungan dari perangkat lainnya seperti arsitektur bangunan mall/tempat event yang dapat memediasi konsumen mengekspresikan gaya hidupnya, bandara sebagai penghubung dan pintu keluar masuk pelaku budaya, majalah, TV dan berbagai hal lainnya.

\section{Referensi}

Abdullah, Irwan. 2006. Konstruksi Dan Reproduksi Kebudayaan. Yogyakarta: Pustaka Pelajar.

Ahimsa-Putra, Heddy Shri. 2003. "Prologue Dari Ekonomi Moral, Rasional Ke Politik Usaha." Pp. 3-59 in Ekonomi Moral, Rasional, dan Politik Dalam Industri Kecil di Jawa. Yogyakarta: Kepel Press.

Armaidy Armawi. 2007. "Dari Konsumerisme Ke Konsumtivisme 
(Dalam Perspektif Sejarah Filsafat Barat)." Jurnal Filsafat 17(3):314-23. doi: 10.22146/jf.23090.

Chaney, David. 2004. Life Styles : Sebuah Pengantar Komprehensif, Terj. Nuraeni. Yogyakarta: Jalasutra.

Chaney, David. 2005. Lifestyles: Sebuah Pengantar Komprehensif. Yogyakarta: Jalasutra.

Douglas, Mary, and Baron Isherwood. 1979. The World of Goods. New York: Basic Books, Inc.

Featherstone, Mike. 2001. Postmodernisme Dan Budaya Konsumen. Yogyakarta: Pustaka Pelajar.

Fiske, Jonn. 1990. Introduction to Communication Studies. Second Edi. United Kingdom: Routledge.

Gandhi, Leela. 2001. Teori Poskolonial: Upaya Meruntuhkan Hegemoni Barat. Yogyakarta: Qalam.

Handoko, Cons. Tr. 2004. "METROSEKSUALITAS DALAM IKLAN SEBAGAI WACANA." NIRMANA 6(2):132-42.

Haryanto Soedjatmiko. 2008. Saya Berbelanja, Maka Saya Ada: Ketika Konsumsi Dan Desain Menjadi Gaya Hidup Konsumeris. Yogyakarta: Jalasutra.

Hendariningrum, Retno, and M. Ed. Susilo. 2014. "Fashion Dan Gaya Hidup: Identitas Dan Komunikasi." Ilmu Komunikasi 6 No.1:25-32.

Ibrahim, Idi Subandi, ed. 2004. Lifestyle Ectasy: Kebudayaan Pop Dalam Masyarakat Komoditas Indonesia. Yogyakarta: Jalasutra.

Jamil, Rabia, Muh. Aryad, and Ambo Upe. 2018. "Perilaku Konsumeris Pengunjung Mall Lippo Plaza Kota Kendari." Neo Societal 3(2):518-28.

Lago, M. N. 2017. "Eksploitasi Tubuh Perempuan Di Media Televisi (Analisis Semiotika Makna Pesan Iklan Cat Avian Syntetic Versi Awas Cat Basah)." Jurnal Online Kinesik, (eJournal) 30(2):30-36.
Lury, Celia. 1998. Budaya Konsumen. Jakarta: Yayasan Obor Indonesia.

Mardiyana, Eva, Lili Adi Wibowo, and Rini Andari. 2012. "Pengaruh Shopping Destination Stratgey Terhadap Keputusan Berkunjung Di Wisata Belanja Mall (Studi Banding Pada Pengunjung Wisata Belanja Mall Kota Makassar)." Tourism and Hospitality Essentials 11(2):315-38.

Miller, Daniel. 1991. "Mass Consumtion", Material Culture and Mass Consumtion. Oxford: T.J Press.

Pertiwi, Tiara Ainun. 2018. "Gaya Hidup Hedonis Pada Penerima Beasiswa Bidikmisi Fakultas Ilmu Sosial Dan Ilmu Politik ( Analisis Pesan Artefaktual )." Kinesik 5(2):101-10.

Raharjo Jati, Wasisto. 2015. "Less Cash Society: Menakar Mode Konsumerisme Baru Kelas Menengah Indonesia." Jurnal Sosioteknologi 14(2):102-12. doi: 10.5614/sostek.itbj.2015.14.2.1.

Rahayu, Yulianita. 2017. "Perilaku Belanja Impulsif Pengunjung Mall Di Kota Bandung." Jurnal EKUIBIS 1(2):11625.

Rumondang, Astri, Acai Sudirman, Samsider Sitorus, Aditya Halim Perdana Kusuma, and Melda Manuhut. 2020. Pemasaran Digital Dan Perilaku Konsumen. edited by A. Rikki. Medan: Yayasan Kita Menulis.

Schlosser, Eric. 2002. Negeri Fast Food. Yogyakarta: Insist Press.

Silalahi, Ulber. 2009. Metode Penelitian Sosial. edited by A. Gunarsa. Bandung: Refika Aditama.

Turner, Bryan S. 2002. Orientalisme, Posmodernisme Dan Globalisme. Jakarta: Riora Cipta 